\title{
Otolith microchemistry reveals the migration patterns of the flathead grey mullet Mugil cephalus (Pisces: Mugilidae) in Korean waters
}

\author{
Seung Eun Bae and Jin-Koo Kim *i)
}

\begin{abstract}
Background: The flathead grey mullet Mugil cephalus has the widest distribution among mugilid species. Recent studies based on mitochondrial DNA sequences showed that the species comprises at least 14 different groups, three of which occur in the northwest Pacific. We analyzed the otolith microchemistry of $M$. cephalus at several locations in Korea to improve understanding of migration pattern and population origin.

Results: We collected 123 sagittal otoliths from seven locations and determined their concentrations of eight elements $\left({ }^{7} \mathrm{Li},{ }^{24} \mathrm{Mg},{ }^{55} \mathrm{Mn},{ }^{57} \mathrm{Fe},{ }^{60} \mathrm{Ni},{ }^{63} \mathrm{Cu},{ }^{88} \mathrm{Sr}\right.$, and $\left.{ }^{138} \mathrm{Ba}\right)$ using laser ablation inductively coupled plasma mass spectrometry. Mean otolith elemental ratios differed significantly among the locations. The Sr:Ca, Fe:Ca, and Ba:Ca ratios were significantly higher than others, and useful chemical signatures for investigating the habitat use of $M$. cephalus populations. We identified five diverse and complicated migration patterns using the otolith data that we collected: estuarine resident (type I), freshwater migrant (type II), estuarine migrant (type III), seawater resident (type IV), and seawater migrant (type V). A canonical discriminant analysis plot revealed separation of two groups (type II in the Yellow Sea vs. other types in remaining locations). Two locations on Jeju Island, despite their close proximity, had fish with quite different migration patterns, corroborating previous molecular studies that distinguished two groups of fishes.
\end{abstract}

Conclusion: We successfully showed that the migration patterns of the Korean mullet varied by location. Only fish from the western sector of Jeju had a unique migration pattern, which is likely confined population in this area. Among the eight otolith elements measured, the Sr:Ca ratio was found to be the best indicator of migration pattern and population origin.

Keywords: Mugil cephalus, Otolith microchemistry, Migration pattern, Korea, Population origin

\section{Background}

Improved understanding of marine fish population dynamics requires (i) the identification of ecologically different populations and (ii) a better knowledge of the life histories of individual fish in coastal and oceanic habitats (Yamane et al. 2012). It is difficult to predict the migration patterns of anadromous and estuarine fishes because of

* Correspondence: taengko@hanmail.net

Department of Marine Biology, Pukyong National University, 45 Yongso-ro, Nam-Gu, Busan 48513, Korea the variability in seasonal, ontogenetic, and sex-related movements among individuals within populations (Secor et al. 1995). Many techniques have been developed for tracking fish movements and discerning connectivity, including natural biological tags (chemical, genetic, and parasitic) and artificial tags (acoustic, artificial chemistry, and archival tags) (Elsdon et al. 2008). Despite advances in external tagging, including acoustic tagging, radio tagging, and satellite telemetry, its application is often limited by budget, battery life, low rates of return, and size

(c) The Author(s). 2020 Open Access This article is licensed under a Creative Commons Attribution 4.0 International License, which permits use, sharing, adaptation, distribution and reproduction in any medium or format, as long as you give appropriate credit to the original author(s) and the source, provide a link to the Creative Commons licence, and indicate if changes were made. The images or other third party material in this article are included in the article's Creative Commons licence, unless indicated otherwise in a credit line to the material. If material is not included in the article's Creative Commons licence and your intended use is not permitted by statutory regulation or exceeds the permitted use, you will need to obtain permission directly from the copyright holder. To view a copy of this licence, visit http://creativecommons.org/licenses/by/4.0/. 
constraints; observations have been largely restricted to the adult phases of top predators (Elsdon et al. 2008; Sturrock et al. 2012).

Otolith microchemistry has recently provided increasingly important signals for reconstructing and tracking the environmental histories of fish. Otolith composition remains unchanged after deposition, and the chemical signals in these structures act as a historical record of environmental conditions (Campana 1999; Campana and Thorrold 2001; Miller et al. 2005; Sturrock et al. 2012). Otoliths are usually composed of calcium carbonate mineralized within a protein matrix. They grow daily and store minor and trace elements during biomineralization processes (Campana 1999). The deposition of otolith carbonate may be regulated by a range of factors, such as age, physiology, environmental stress, food availability, ambient temperature, diurnal and seasonal cycles, and the movement of individual fishes (Radtke and Shafer 1992). Because of these effects, otolith microchemistry can provide important data on migratory behavior and environmental factors. The level of gene flow can also be discerned when these data are combined with information on neutral genetic makers.

Mugil cephalus is a cosmopolitan euryhaline fish that is distributed in coastal, lagoonal, and estuarine waters between latitudes $42^{\circ} \mathrm{N}$ and $42^{\circ} \mathrm{S}$. Recent studies have shown that the species comprises at least 14 different sub-groups, three of which exist in Taiwan. Shen et al. (2011) showed that the three groups are reproductively isolated, and that gene flow is therefore restricted. Appropriate conservation and management of species require information on the origins of each population and the connectivity among nursery areas. Previous investigations have revealed the life history cycle of $M$. cephalus and the diverse aquatic environments that the fish occupy at different life cycle stages. Some individuals remain in an environment of uniform salinity for extended periods of time (residents), while others regularly move among environments of differing salinities (migrants) (Chang et al. 2004; Wang et al. 2010; Fowler et al. 2016). It was recently shown that $M$. cephalus has more diverse migratory patterns than previously realized; estuarine resident, freshwater migrant, estuarine migrant, and seawater resident patterns have been identified (Fortunato et al. 2017). The estuarine-dependent populations have patterns of dispersal, retention, or physiological preference within specific salinity ranges; salinity may act directly or indirectly on controlling migration (Secor and Rooker 2000).

Although three genetic groups of $M$. cephalus in Taiwan have overlapping distribution ranges, they may have different patterns of migration and habitat usage among different coastal environments, reflecting adaptation across a wide range of environmental conditions
(Chang et al. 2004; Ke et al. 2009; Wang et al. 2010). Korean ocean waters have a complexity of structures and currents flows across time and space. Seasonal changes in environmental parameters in particular locations may influence gene flow patterns and the population structure of marine organisms (Kim et al. 2017; Bae et al. 2020a). Two genetic groups of $M$. cephalus have recently been identified in Korean waters. Gene flow between the groups is restricted, suggesting that they may be reproductively isolated (Bae et al. 2020b).

In the current study, we aimed to answer the following questions: (i) does otolith elemental composition vary significantly by geographic location? and (ii) is the genetic grouping of $M$. cephalus related to previously described migration patterns?

\section{Materials and methods}

\section{Sample and otolith preparation}

A total of 123 individuals were collected from seven locations in Korean waters (Fig. 1). The samples were collected by fishing, fishing nets, and local fish markets between 2017 and 2019: Yangyang (YY, $n=16,290$ $340 \mathrm{~mm}$ in TL) in the East Sea, Busan (BS, $n=19,187-$ $317 \mathrm{~mm}$ in TL), Yeosu, (YS, $n=21,210-242 \mathrm{~mm}$ in TL), Wando (WD, $n=20,375-535 \mathrm{~mm}$ in TL) in the Korean Strait, Jungmoon (JM, $n=13,172-393 \mathrm{~mm}$ in TL), and Hangyeong (HG, $n=20,53-75 \mathrm{~mm}$ in TL) off Jeju Island, and Mokpo + Gunsan (MP + GS, $n=14,387-452$ $\mathrm{mm}$ in TL) in the Yellow Sea. Prior to specimen preservation, sagittal otoliths were extracted and stored in deionized water or $95 \%$ ethanol; the elemental composition and structure of otoliths are not strongly affected by ethanol (Proctor and Thresher 1998). The right side of the otolith from all fish was embedded separately in epoxy resin and sectioned in the transverse plane using a saw fitted with a diamond-coated blade. Individual otolith sections were then polished with 1200 and 3400 silicate abrasive papers to expose the cores. The otoliths were photographed using a digital camera.

\section{Otolith elemental analysis}

Otoliths were analyzed for the concentrations of nine elements $\left({ }^{7} \mathrm{Li},{ }^{24} \mathrm{Mg},{ }^{43} \mathrm{Ca},{ }^{55} \mathrm{Mn},{ }^{57} \mathrm{Fe},{ }^{60} \mathrm{Ni},{ }^{63} \mathrm{Cu},{ }^{88} \mathrm{Sr}\right.$, and ${ }^{138} \mathrm{Ba}$ ) by laser ablation inductively coupled plasma mass spectrometry. Nine elements were known as the most likely abundant and informative elements to serve as environmental tags indicators (Campana 2005; Moreira et al. 2018). These elements were routinely used to infer past location in fish $(\mathrm{Li}, \mathrm{Mg}, \mathrm{Mn}, \mathrm{Cu}$, $\mathrm{Sr}$, and $\mathrm{Ba}$ ) and to serve as environmentally influenced stock markers ( $\mathrm{Ni}$ and Fe) (Camapan 2005; Sturrock 2012). Among them, hard acid ions such as $\mathrm{Li}, \mathrm{Mg}, \mathrm{Ca}, \mathrm{Sr}$, and Ba typically have a residence time longer than the mixing time of the ocean and 


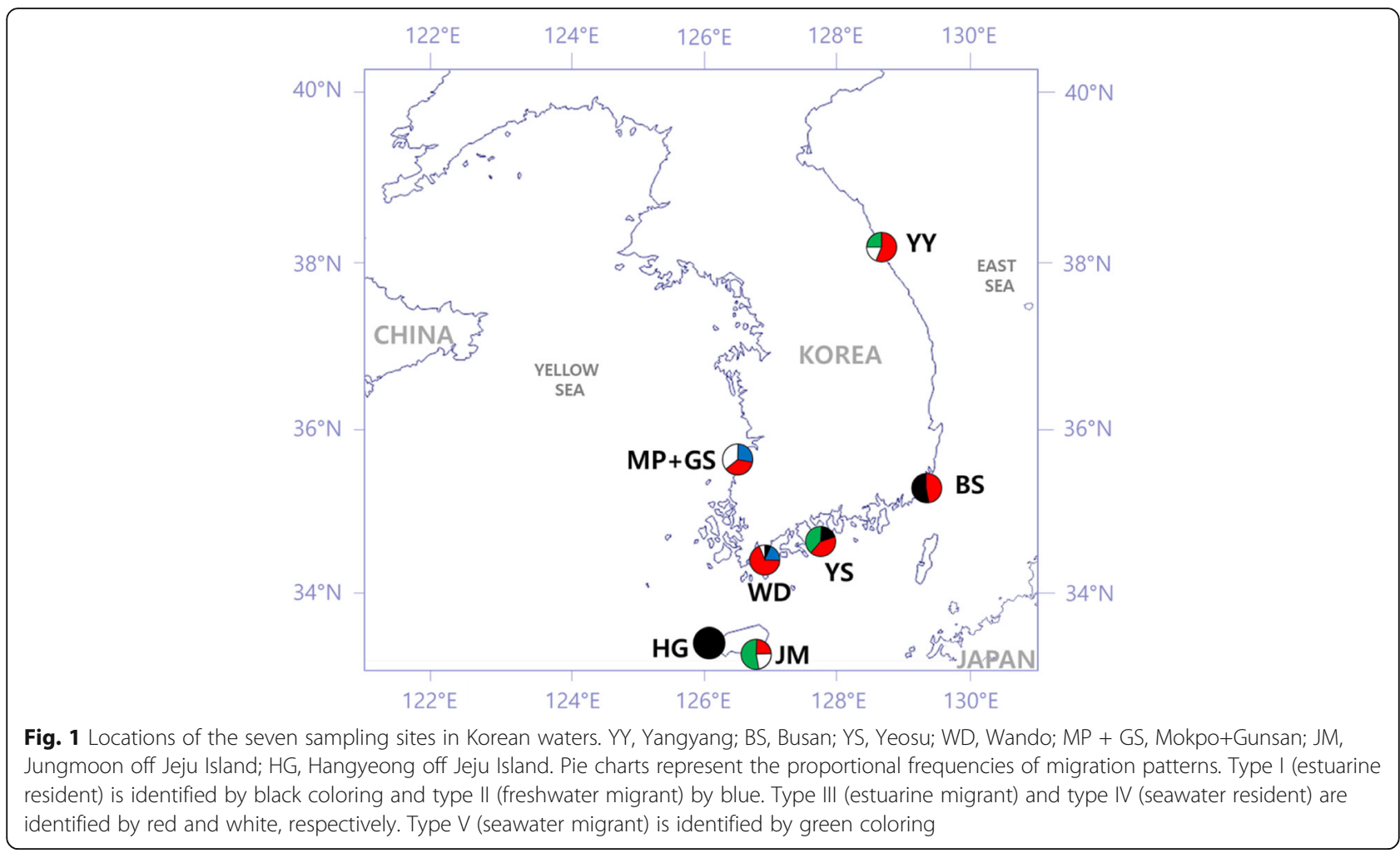

consequently, their concentrations tend to vary with salinity. On the other hand, soft and intermediate acid ions such as $\mathrm{Cu}$ and $\mathrm{Mn}$ are relatively weak, and they have characteristics making soft elements reactive and readily removed from seawater (Sturrock 2012). The laser spot energy density was set by the pulse frequency rate $(10 \mathrm{~Hz})$, beam diameter, and ablation rate. All elemental concentrations were standardized against the National Institute of Standards and Technology 612 glass standards (Pearce et al. 1997). The concentrations of all elements in the otoliths were transformed to element:Ca ratios. Microchemical concentrations were expressed as molar or micro ratios.

\section{Statistical analyses}

We used IBM SPSS Statistics version 22 (IBM Corp, Armonk, NY, USA), and the JMP software (Jones and Sall 2011) to identify statistically significant differences, and all element: $\mathrm{Ca}$ ratios were log-transformed for the statistical analyses. The measuring area of each otolith spanned the zone from the otolith central core to $1000 \mu \mathrm{m}$ toward the perimeter. This area may include the early life history period of $M$. cephalus. Data were collected from the corresponding distances of the elemental profiles. Each element:Ca ratio was compared among sampling sites using the non-parametric Kruskal-Wallis test, because the elemental compositions of the otolith core region were not normally distributed, and the variance was not homogeneous among locations. We used Bonferroni correction with Kruskal-Wallis test to obtain a 0.05 level of significance. Pearson's correlation analysis was used to examine the relationships between the elemental ratios in the otoliths. CDA (canonical discriminant analyses) were used to assess the ability of otolith elemental ratios to identify the origin of each population.

As previously suggested by Fortunato et al. (2017), we classified the migration pattern for each specimen based on the Sr:Ca ratio. An Sr:Ca ratio $<3 \times 10^{-3} \mathrm{mmol} / \mathrm{mol}$ indicated a freshwater origin, that between $3 \times 10^{-3}$ and $7 \times 10^{-3} \mathrm{mmol} / \mathrm{mol}$ indicated an estuarine origin, and that $>7 \times 10^{-3} \mathrm{mmol} / \mathrm{mol}$ indicated a marine origin. Canonical discriminant analyses were also performed to verify the correct assignment of individuals to migration patterns.

\section{Results}

\section{Elemental otolith microchemistry}

The average values and deviations of otolith element:Ca ratios in the zone from the otolith central core to $1000 \mu \mathrm{m}$ toward the perimeter are listed in Table 1. All of the ratios varied significantly among locations (KruskalWallis test, $P<0.05$; Table S1). Some of the correlations between elemental ratios were significant (Pearson correlation analysis, $P<0.05$, Table 2 ). The correlation between 
Table 1 Means and standard deviations for Mugil cepahlus otolith element:Ca ratios in the zone from the otolith central core to $1000 \mu \mathrm{m}$ toward the perimeter according to location in Korea

\begin{tabular}{llllllllll}
\hline Location & $N$ & Li:Ca & Mg:Ca & Mn:Ca & Fe:Ca & Ni:Ca & Cu:Ca & Sr:Ca & Ba:Ca \\
\hline YY & 16 & $1.082 \pm 0.156$ & $0.068 \pm 0.011$ & $0.018 \pm 0.017$ & $0.220 \pm 0.013$ & $3.081 \pm 0.510$ & $4.039 \pm 2.491$ & $6.400 \pm 0.848$ & $0.036 \pm 0.026$ \\
BS & 19 & $2.458 \pm 0.576$ & $0.099 \pm 0.024$ & $0.015 \pm 0.011$ & $0.414 \pm 0.077$ & $4.949 \pm 0.491$ & $10.621 \pm 5.697$ & $5.494 \pm 0.715$ & $0.060 \pm 0.037$ \\
YS & 21 & $1.040 \pm 0.216$ & $0.095 \pm 0.019$ & $0.008 \pm 0.003$ & $0.284 \pm 0.021$ & $3.387 \pm 0.199$ & $4.043 \pm 2.943$ & $5.564 \pm 0.995$ & $0.043 \pm 0.034$ \\
WD & 20 & $2.782 \pm 1.570$ & $0.138 \pm 0.042$ & $0.051 \pm 0.050$ & $0.319 \pm 0.030$ & $4.706 \pm 0.484$ & $6.073 \pm 2.254$ & $4.804 \pm 1.358$ & $0.051 \pm 0.042$ \\
JM & 13 & $0.948 \pm 0.307$ & $0.093 \pm 0.021$ & $0.008 \pm 0.004$ & $0.248 \pm 0.055$ & $3.857 \pm 0.697$ & $3.801 \pm 1.563$ & $7.043 \pm 0.782$ & $0.063 \pm 0.049$ \\
HG & 20 & $3.763 \pm 4.434$ & $0.136 \pm 0.116$ & $0.005 \pm 0.002$ & $0.300 \pm 0.051$ & $5.151 \pm 2.719$ & $4.899 \pm 1.725$ & $4.435 \pm 0.424$ & $0.013 \pm 0.003$ \\
MP + GS & 14 & $1.253 \pm 0.525$ & $0.098 \pm 0.029$ & $0.050 \pm 0.089$ & $0.231 \pm 0.029$ & $3.736 \pm 1.106$ & $6.051 \pm 6.892$ & $5.672 \pm 1.886$ & $0.035 \pm 0.039$
\end{tabular}

YY Yangyang, BS Busan, YS Yeosu, WD Wando, JM Jungmoon in Jeju Island, HG Hangyeong in Jeju Island, MP + GS Mokpo+Gunsan

the ratios $\mathrm{Fe}: \mathrm{Ca}$ and $\mathrm{Cu}: \mathrm{Ca}$ showed a significantly positive relationship ( $r=0.453, P<0.01$ ), whereas the $\mathrm{Sr}$ :Ca ratio was significantly negatively correlated with the $\mathrm{Mn}: \mathrm{Ca}$ and Ba:Ca ratios $(r=-0.282$ and -0.280 , respectively, $P<0.01$, Table 2).

The first axis of the CDA explained $61.1 \%$ of the total variation. The major discriminant factor in the first axis $(\mathrm{CAN1}$ ) was the Fe:Ca ratio (eigenvalue $=3.301$ ) (Table S2). The first axis contributed especially toward discriminating between locations BS, WD, or HG and the remaining four (Fig. 2). The second canonical function explained the remainder of the dispersion in the data; $28.4 \%$ of the variation in the second axis (CAN2) was attributed to differences between BS and HG (Table S2, Fig. 2). The main discriminant factor in the second axis was the $\mathrm{Ba}$ :Ca ratio. The rate of location reclassification ranged from 42.9\% (MP + GS) to $95.0 \%$ (HG). Therefore, HG and BS were distinct from the other locations in terms of the Fe: $\mathrm{Ca}$ and $\mathrm{Ba}: \mathrm{Ca}$ ratios based on the first and second discriminant axis.

\section{Migration patterns}

Otolith concentrations of $\mathrm{Sr}$ and $\mathrm{Ba}$ can provide information on habitat and migration patterns over the lifetime of individual fish. The $\mathrm{Sr}$ :Ca ratio ranged from 4.43 (HG) to $7.04 \mathrm{mmol} / \mathrm{mol}$ (JM) (Table 1 ). We detected five migration patterns based on these ratios (Fig. 3). Type I refers to residing in an estuarine environment exclusively (estuarine resident); type II refers to migration from a freshwater habitat during early life to an estuarine or seawater habitat during adulthood (freshwater migrant); type III refers to migration from an estuarine environment during early life to seawater later (estuarine migrant); type IV refers to residing in a marine habitat exclusively (seawater resident); and type $\mathrm{V}$ refers to migration from a seawater habitat during early life to estuarine waters later (seawater migrant).

The otolith microchemistries of most locations were indicative of the type III migration pattern (estuarine migratory). The type II pattern was least common, occurring only at WD in the western Korea Strait and at MP + GS in the Yellow Sea (Table 3). Most locations exhibited more than two migratory patterns, whereas HG exhibited only the type I pattern (estuarine resident) (Table 3, Fig. 1). CDA showed that individuals of each type were accurately assigned to the original type, with > $50 \%$ accuracy. Type IV had the highest proportion of correct assignments (> 90\%), and type III had the lowest proportion (57.9\%) (Table 4). The CDA plot showed a clear separation of two groups (type II vs. other types) based on the first discriminant axis (Fig. 4). The variable

Table 2 Pearson correlation coefficients for the relationships among eight elemental ratios in the otoliths of Mugil cephalus collected from seven locations in Korean waters

\begin{tabular}{|c|c|c|c|c|c|c|c|c|}
\hline & Li:Ca & Mg:Ca & $\mathrm{Mn}: \mathrm{Ca}$ & $\mathrm{Fe}: \mathrm{Ca}$ & $\mathrm{Ni}: \mathrm{Ca}$ & Cu:Ca & Sr:Ca & $\mathrm{Ba}: \mathrm{Ca}$ \\
\hline \multicolumn{9}{|l|}{ Li:Ca } \\
\hline $\mathrm{Mg}: \mathrm{Ca}$ & 0.154 & & & & & & & \\
\hline $\mathrm{Mn}: \mathrm{Ca}$ & 0.020 & $0.179^{*}$ & & & & & & \\
\hline Fe:Ca & 0.124 & 0.164 & 0.019 & & & & & \\
\hline $\mathrm{Ni}: \mathrm{Ca}$ & $0.312^{* *}$ & 0.122 & 0.001 & $0.378^{* *}$ & & & & \\
\hline $\mathrm{Cu}: \mathrm{Ca}$ & 0.044 & 0.119 & 0.107 & $0.453^{* *}$ & $0.278^{* *}$ & & & \\
\hline Sr:Ca & $-0.245^{* *}$ & $-0.175^{*}$ & $-0.282^{* *}$ & $-0.244^{* *}$ & -0.114 & -0.015 & & \\
\hline Ba:Ca & $-0.193^{*}$ & 0.020 & $0.370^{* *}$ & 0.101 & -0.079 & 0.038 & $-0.280^{* *}$ & \\
\hline
\end{tabular}

${ }^{*} P<0.05$

${ }^{* *} P<0.01$ 


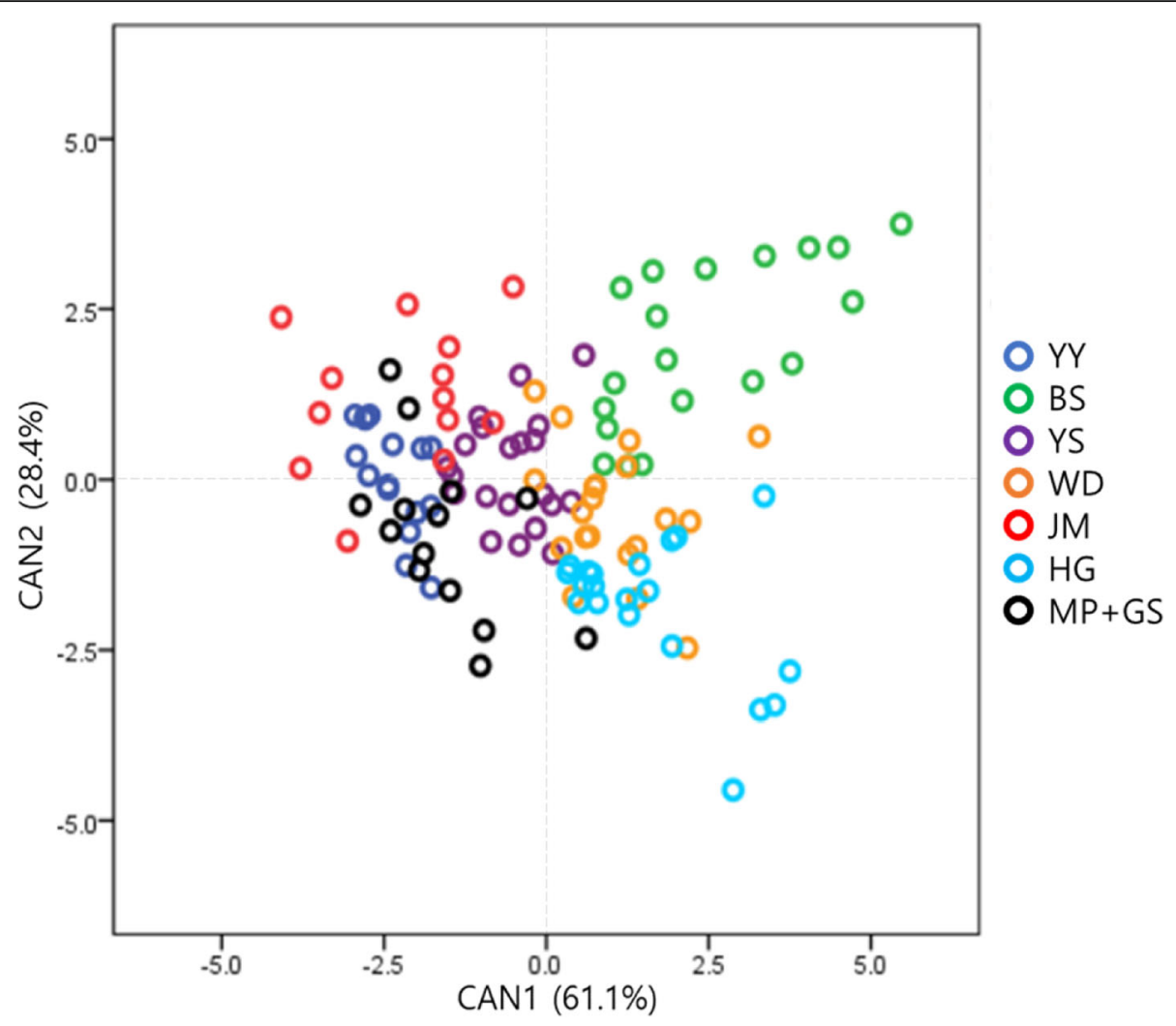

Fig. 2 Two-dimensional canonical discriminant analysis plot of seven Korean locations based on the otolith microchemistry of Mugil cephalus. CAN1 and CAN2 are the first and second axes of the analysis. The percentages in parentheses are the proportions of total variation explained by each of the two axis. YY, Yangyang; BS, Busan; YS, Yeosu; WD, Wando; MP + GS, Mokpo+Gunsan; JM, Jungmoon in Jeju Island; HG, Hangyeong in Jeju Island

that best explained the first axis variation was the $\mathrm{Sr}: \mathrm{Ca}$ ratio (eigenvalue $=2.765$, Table S3).

\section{Discussion}

\section{Spatial variation in otolith microchemistry}

The elemental concentrations in otoliths differed significantly among locations. These concentrations are strongly related to the chemical compositions of the environment in which individuals reside during a particular period of time (Campana 1999; Campana and Thorrold 2001). The ratios of $\mathrm{Ba}, \mathrm{Fe}, \mathrm{Cu}, \mathrm{Ni}, \mathrm{Mn}$, and $\mathrm{Sr}$ are correlated with environmental indicators such as salinity (Campana 1999; Chang et al. 2012; Daros et al. 2016). In particular, $\mathrm{Sr}$ and Ba concentrations are negatively correlated with salinity (Campana 1999; Elsdon and Gillanders 2005; Wang et al. 2010). We found that $\mathrm{Sr}$ and Ba were negatively correlated $(r=-0.280, P<0.01)$, in line with previous studies. In our CDA analysis, HG and BS were distinct from the other locations in terms of the $\mathrm{Fe}: \mathrm{Ca}$ and $\mathrm{Ba}$ :Ca ratios measured in otoliths, suggesting that $\mathrm{HG}$ and $\mathrm{BS}$ are relatively heterogeneous in their chemical compositions. Three elemental ratios, including $\mathrm{Fe} \mathrm{Ca}$, previously measured in the otoliths of juvenile pelagic shortbelly rockfish (Sebastes jordani) were used to discriminate among the populations residing in different water masses; these otolith signatures were good predictors of water mass residency (Nishimoto et al. 2010). Dicentrachus labrax specimens living at two different locations had distinct otolith concentrations of some elements; elevated concentrations $\mathrm{Fe}$ and $\mathrm{Mn}$ in these otoliths may reflect the natural release of trace metals from sediments into seawater (Traina et al. 2015). High concentrations of Fe may be attributed to the presence of large quantities of organic particulate matter introduced by rivers or terrestrial runoff. We found that otolith $\mathrm{Sr}: \mathrm{Ca}, \mathrm{Ba} \mathrm{Ca}$, and Fe:Ca ratios are useful natural markers for distinguishing among $M$. cephalus specimens from diverse environments.

In our study, the $\mathrm{Sr}: \mathrm{Ca}$ and $\mathrm{Ba}: \mathrm{Ca}$ raitos were highest at JM (southern Jeju Island) and lowest at HG (western Jeju Island). Jeju Island is directly influenced by range of ocean currents and water mass movements, such as the Kuroshio Current, Taiwan Current, Changjiang diluted water (CDW) of the East China Sea, yellow bottom water, and river inflows to the South Sea. All of these flows are subject to large seasonal variations (Ko et al. 2007; Lie and Cho 2016; Lim et al. 2017). The Tsushima 


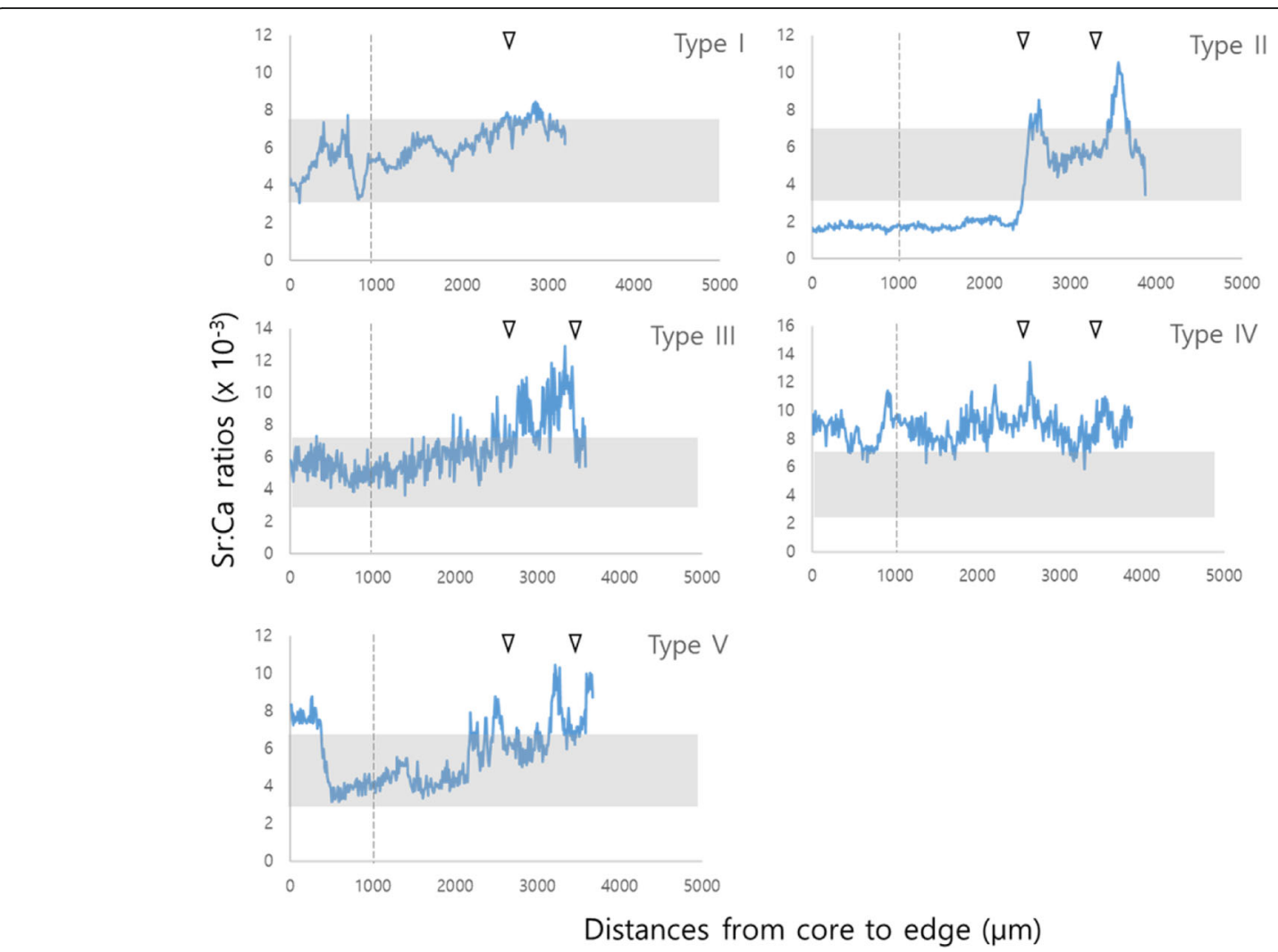

Fig. 3 Five migration patterns of Mugil cephalus inferred by the Sr:Ca ratios in the zone spanning from the otolith core to $1000 \mu \mathrm{m}$ toward the perimeter. Data were collected from seven locations in Korean waters. The gray horizontal bar shows the critical levels for the environmental limits based on water salinity (following Chang et al. 2004). Type I, estuarine resident; type II, freshwater migrant; type III, estuarine migrant; type IV, seawater resident; type $V$, seawater migrant. White down-pointing triangle indicates the otolith annual ring. Distances refer to the span (in micrometer) from the otolith core the perimeter

Current and Cheju Warm Current, which are branches of the Kuroshio Current, contain warm waters with salinities; they are the major flows affecting the formation of water masses around Jeju Island. In winter, a tongueshaped thermohaline front forms between the Cheju Warm Current and coastal waters (Lie et al. 2009;

Table 3 The occurrence of five Mugil cephalus migration patterns at seven sites, inferred from Sr:Ca ratios in the zone spanning the otolith core to $1000 \mu \mathrm{m}$ toward the perimeter

\begin{tabular}{lllllllll}
\hline & YY & BS & YS & WD & JM & HG & MP + GS & Total \\
\hline Type I & 0 & 9 & 4 & 1 & 0 & 20 & 0 & 34 \\
Type II & 0 & 0 & 0 & 4 & 0 & 0 & 4 & 8 \\
Type III & 9 & 10 & 9 & 14 & 3 & 0 & 5 & 50 \\
Type IV & 3 & 0 & 0 & 1 & 3 & 0 & 5 & 12 \\
Type V & 4 & 0 & 8 & 0 & 7 & 0 & 0 & 19 \\
\hline
\end{tabular}

YY Yangyang, BS Busan, YS Yeosu, WD Wando, JM Jungmoon in Jeju Island, $H G$ Hangyeong in Jeju Island, MP + GS Mokpo+Gunsan

Type I estuarine resident, Type I/ freshwater migrant, Type III estuarine migrant, Type IV seawater resident, Type $V$ seawater migrant

The proportions of the correct classification determined by canonical discriminant function analysis are presented in Fig. 1
Hwang et al. 2014). However, the northeastward spreading of the Changjiang flow brings diluted low salinity water to the western side of Jeju Island in summer (Lie and Cho 2016; Lim et al. 2017). Thus, there are large differences in water salinity between summer and winter off Jeju Island, and the annual salinity values are higher off the eastern coast of Jeju Island and in the East Sea than off the western coasts of this island (Park et al. 2015). Furthermore,

Table 4 The correct classification rate of the canonical discriminant analysis of otolith for each migratory pattern. Number of individuals which included in original patterns are shown in brackets

\begin{tabular}{lllllll}
\hline & Type I & Type II & Type III & Type IV & Type V & Total \\
\hline Type I & 76.5 & 2.9 & 20.6 & & & $34(26)$ \\
Type II & 25.0 & 75.0 & & & & $8(6)$ \\
Type III & 18.0 & 2.0 & 60.0 & 6.0 & 14.0 & $50(30)$ \\
Type IV & & & & 91.7 & 8.3 & $12(11)$ \\
Type V & & & 15.8 & 26.3 & 57.9 & $19(11)$ \\
\hline
\end{tabular}

Type I estuarine resident, Type II freshwater migrant, Type III estuarine migrant, Type IV seawater resident, Type $V$ seawater migrant 


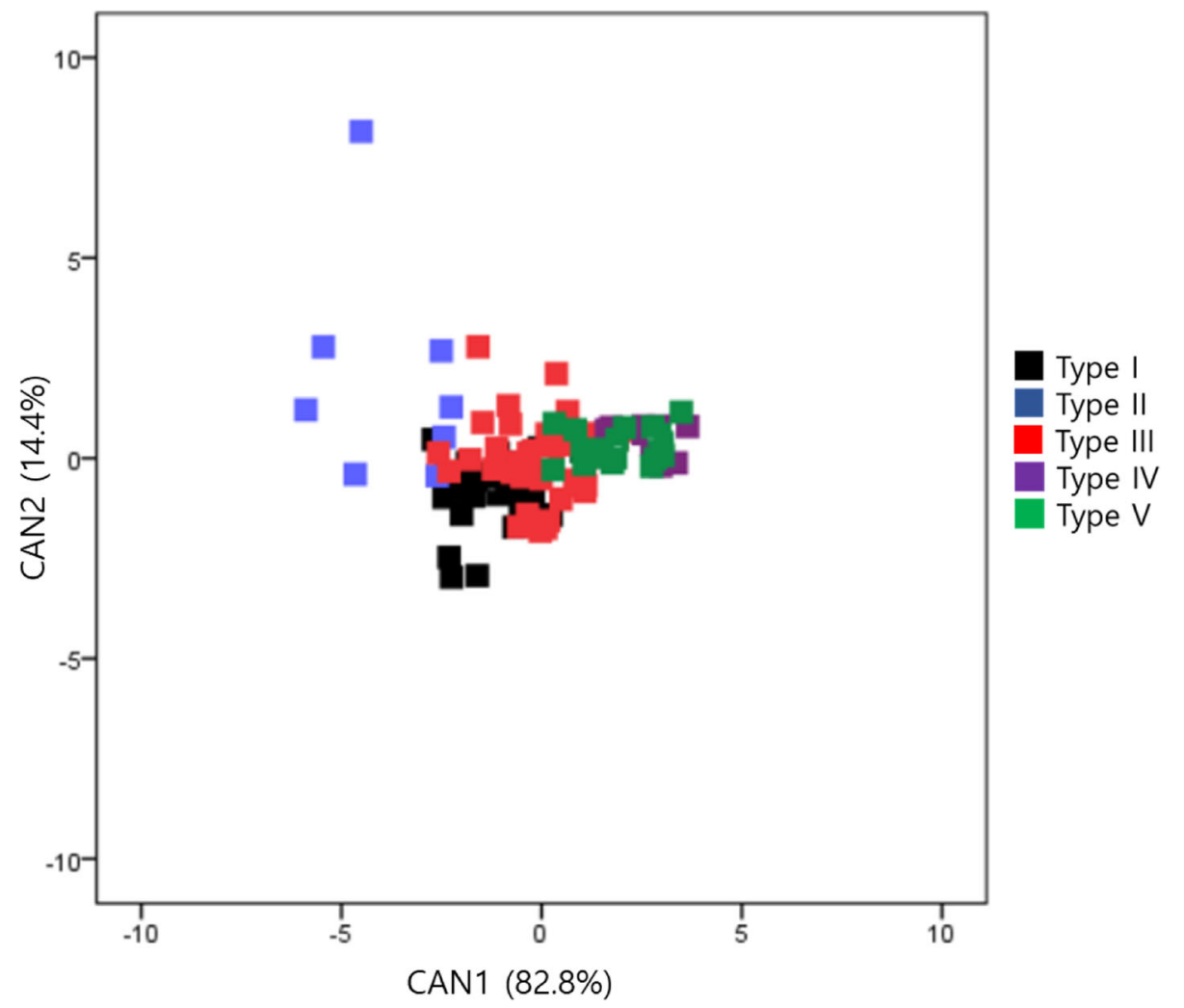

Fig. 4 Two-dimensional canonical discriminant analysis (CDA) plot (first and second canonical axes included) of five Mugil cephalus migration patterns based on otolith microchemistry. Type I, estuarine resident; type II, freshwater migrant; type III, estuarine migrant; type IV, seawater resident; type $V$, seawater migrant. The percentages in parentheses are the proportions of total variation explained by each of the two axis

temperature, salinity, and the dissolved oxygen concentration vary among locations and seasons. Temperature also significantly affects the incorporation of $\mathrm{Sr}$ and $\mathrm{Ba}$ into the otoliths of larval Pacific cod (DiMaria et al. 2010). Overall, environmental parameters and their seasonal variability at each location appear to affect the incorporation of elements into the otoliths of individual fishes.

\section{The influence of environmental factors on migratory patterns}

Our study provided the first evidence for the five migratory patterns in Korean M. cephalus. The variation in migratory patterns among individuals was reflected in the measured $\mathrm{Sr}: \mathrm{Ca}$ ratios, which revealed diversity in habitat use and migration over the lifetime of different individuals.

Our CDA analysis showed that the type II migration pattern was distinguished from others based on the $\mathrm{Sr}$ : Ca ratio, suggesting that $M$. cephalus in the Yellow Sea (MP + GS) and the western Korea Strait (WD) (fish migration patterns at both sites were classified as type II) may have a migration pattern distinct from those in other locations. Type II fish are freshwater migrants that prefer low-salinity and freshwater habitats during early life. According to Chang and Iizuka (2012), adults of mugilids can migrate to freshwater environments to avoid competition, which suggests the existence of specific ecological niches. In Taean, adults of $M$. cephalus tend to be collected, indicating that the larvae stayed in estuarine or freshwater and then migrate to the coastal water after they reach sexual maturity (Hong et al. 2014). Therefore, WD and MP + GS may have a similar migration pattern. This strong freshwater effect was not evident in other migration types. There are major freshwater inputs into the Yellow Sea (Han, Geum, and Yeongsan Rivers). Furthermore, the flow of the lowsalinity Korean Coastal Currents changes seasonally along Korean coastlines (Yang and Youn 2007; Hwang et al. 2014). According to Park et al. (2017), when compared to spatiotemporal distribution characteristics of salinity in the coastal waters of Korea, the salinity was relatively lower off the western coasts, which have a greater discharge of freshwater and high tide than the eastern coasts throughout the year (Fig. S1). In addition, the salinity variability between 2017 and 2019 showed similar tendency (Fig. S2), indicating that these variabilities of salinity in coastal waters may have the correlation with Sr:Ca ratios. These particular environmental 
characteristics may be related to fish migration patterns and population structures. Many previous studies have shown that the diverse ocean currents and water masses around Korea may affect the population structures of marine fish (Kim et al. 2017; Bae et al. 2020a). For example, Takifugu niphobles comprises two genetic groups that are geographically separated (Yellow Sea vs. East Sea + Korea Strait). This may be evidence of gene flow restriction between two groups mediated by oceanographic processes that have promoted local environmental adaptation, which is expressed through different habitat uses (Bae et al. 2020a).

Our study identified for the first time a seawater migrant pattern in which fish moved from marine waters to estuaries during the early life stages, followed by irregular movements between estuarine and offshore waters during later life. The seawater migrant pattern was very frequent at JM off the southern coast of Jeju Island. The estuarine resident pattern was most frequent at HG on the western shore of Jeju Island. The complex spawning behavior of $M$. cephalus is related to water column height and salinity changes with temperature (Ibáñez and Gutierrez-Benitex 2004). As mentioned, these different migration patterns may be influenced by the oceanic currents around Jeju Island. In particular, the southern coastal waters may be affected by complex hydrographic factors, such as submarine groundwater discharge, streams near the Chenjiyeon and Jeongbang waterfalls (Lee and Kim 2007, Yoon 2016; Kwon et al. 2018), and/ or the high-temperature/high-salinity Tsushima Warm Current (Choi et al. 2008). Furthermore, the western and southern coasts of Jeju Island are dominated by different combinations of salinity and temperature (low salinity and low temperature vs. high salinity and high temperature), a difference that is expressed in the community structures of phytoplankton (Lee et al. 2009; Kwon et al. 2018) and fish (Choi et al. 2008). Thus, these seasonal and spatial variations in environmental parameters could be important factors in population structuring and the habitat selection of individuals.

\section{Inferring population structure and origin}

We found that $M$. cephalus individuals in most locations showed a variety of migratory patterns, which may indicate a mixture of multiple spawning populations. Previous studies also identified mixtures of migratory and resident $M$. cephalus near Taiwan, thereby demonstrating the existence of multiple cohorts and/or specific ecological features in M. cephalus (Chang et al. 2000, 2004; Ke et al. 2009; Wang et al. 2010; Chang and Iizuka, 2012). Wang et al. (2011) showed that M. cephalus can be divided into three types: marine, brackish water, and freshwater types, as revealed by temporal changes in otolith microchemistry. We found that the brackish type was predominant and the freshwater type rare $(0.07 \%)$, suggesting the existence of potential population structures originating from different nursery grounds. In most of the locations we evaluated, $M$. cephalus had estuarine-origin and migratory patterns, indicating that the species tends to move into estuaries during early life. After the larvae passively drift into estuaries, the juveniles undergo physiological and morphological shifts and experience changes in a gradient of environmental factors as they transition toward the nursery habitat (Hsu et al. 2009; Zydlewski and Wilkie 2012). The juveniles of $M$. cephalus are generally very dependent on freshwater and oligohaline habitats, because living in a fully marine habitat would require a large energy expenditure for osmoregulation. Adults migrate to optimal-salinity habitats to benefit from the lowest energy expenditure and highest growth rate (Cardona 2000; Fazio et al. 2013; Wang 2014; Gorski et al. 2015). Based on otolith annual rings described by Zhang et al. (2011), most of the types in our study became apparent over 2 years, revealing a high rate of residing in the estuaries and in seawater during aging. Our findings were concordant with those of Chang et al. (2004), showing that adult M. cephalus tend to migrate to higher-salinity offshore waters as they grow.

Chemical environments vary among different natal areas, and juvenile $M$. cephalus can be expected to show distinct chemical signatures representative of their natal habitats (Morrison et al. 2016). We showed that type III was the dominant migration pattern in Korean $M$. cephalus, and this finding suggests that populations may share nursery grounds. However, $M$. cephalus specimens from HG (western sector of Jeju Island) were characterized only as type I (estuarine resident) and had lower elemental ratios ( $\mathrm{Sr}: \mathrm{Ca}$ and $\mathrm{Ba}: \mathrm{Ca})$ compared with those found in other locations. This indicates that the population may be confined to HG. Similarly, the different microchemical ratios ( $\mathrm{Li}, \mathrm{Mg}$, and $\mathrm{Mn}$ ) in Thunnus orientalis otoliths indicate that the populations are divided into two potential nursery areas (East Sea + East China Sea vs. Pacific Ocean) (Rooker et al. 2001). We found two migration patterns off Jeju Island (migratory in JM and resident in HG). The spatial and temporal differences in spawning migration patterns can also affect the genetic structure of $M$. cephalus (Ke et al. 2009; Shen et al. 2011, 2015). Mitochondrial DNA sequences showed that $M$. cephalus in Korean waters comprises two groups (Mugil sp. C, NWP1 and Mugil sp. I, NWP2), and these two groups coexist only off Jeju Islands (Bae et al. 2020b). These genetic findings are concordant with our results showing the presence of two potential populations. Both otolith microchemistry and molecular markers have been used recently to identify unique population structural characteristics 
(Miller et al. 2005; Liu et al. 2010; Collins et al. 2013; Taillebois et al. 2017). Therefore, the migration patterns we detected may indicate multiple origins of $M$. cephalus in Korean waters.

\section{Conclusion}

The otolith Sr:Ca ratios that we measured revealed five migration patterns among $M$. cephalus populations in Korean waters. Most individuals had estuaries origins, indicating that they used estuaries as nursery grounds. Most locations had fish with diverse migration patterns. Some individuals in the Yellow Sea and in the western Korea Strait remained in environments with very low salinities, and tend to migrate to the offshore after they reach sexual maturity. This showed that they have the adaptability to tolerate a wide range of environmental conditions. Therefore, the habitat use of flathead grey mullet can change with age according to the optimal conditions for survival and growth. Completely different migration patterns were found between $M$. cephalus specimens collected from two locations off Jeju Island (type I only in HG vs. types III, IV, and V in JM). This difference may be due to the dominating influence of the Tsushima Warm Current and/or coastal waters, including the discharge of submarine freshwater and waterfalls at JM, resulting in the occurrence of two different groups (a migratory group at JM and a resident group at HG). The diversity of the M. cephalus may reflect flexible adaptation to local environments.

\section{Supplementary information}

Supplementary information accompanies this paper at https://doi.org/10. 1186/s41610-020-00164-9.

Additional file 1: Table S1. Kruskal-Wallis H-tests for significant differences among locations in Mugil cephalus otolith element:Ca ratios in the zone spanning from the otolith core to $1000 \mu \mathrm{m}$ toward the perimeter.

Table S2. Standardized canonical (CAN) coefficients for eight elements ratios. The eight elements were ${ }^{7} \mathrm{Li},{ }^{24} \mathrm{Mg},{ }^{55} \mathrm{Mn},{ }^{57} \mathrm{Fe},{ }^{60} \mathrm{Ni},{ }^{63} \mathrm{Cu},{ }^{88} \mathrm{Sr}$, and ${ }^{138} \mathrm{Ba}$. They were measured at seven Korean locations in Mugil cephalus otoliths in the zone spanning from the otolith core to $1000 \mu \mathrm{m}$ toward the perimeter. CAN1-CAN6 are the axes of the canonical discriminant analysis. Table S3. Standardized canonical (CAN) coefficients based on eight elemental ratios ( ${ }^{7} \mathrm{Li},{ }^{24} \mathrm{Mg},{ }^{55} \mathrm{Mn},{ }^{57} \mathrm{Fe},{ }^{60} \mathrm{Ni},{ }^{63} \mathrm{Cu},{ }^{88} \mathrm{Sr}$, and ${ }^{138} \mathrm{Ba}$ ) in the five migration patterns of $M$. cephalus. CAN1-CAN4 are the axes of the canonical discriminant analysis. Fig. S1. The distributions of salinity in (a) February, (b) May, (c) August, and (d) November in the coastal area of Korea in 2015. Data were obtained from the Park et al. (2017). Fig.

S2. The variability of salinity in the coastal area of Korea between 2017

and 2019. Data were obtained from the MEIS (Marine Environment Information System) (https://www.meis.go.kr)

\section{Abbreviations \\ CDA: Canonical discriminant analysis; CDW: Changjiang diluted water; NWP: Northwest Pacific}

\section{Acknowledgements}

We would like to deeply thank Myoung SH, Yu HJ, Lee WJ, Kim JS, and Lee $\mathrm{JH}$ from the Ichthyological laboratory in Pukyong National University for help with collecting samples.

\section{Authors' contributions}

SEB designed the study, performed the experiments and data analysis, and wrote the manuscript. JKK participated in the design of the study and reviewed/edited the manuscript. All authors read and approved the final manuscript.

\section{Funding}

This research was supported by the Marine Biotechnology Program of the Korea Institute of Marine Science and Technology Promotion (KIMST) funded by the Ministry of Oceans and Fisheries (MOF) (No. 20170431).

\section{Availability of data and materials}

The datasets generated during and/or analyzed during the current study are available from the corresponding author on reasonable request.

\section{Ethics approval and consent to participate}

Not applicable.

\section{Consent for publication}

Not applicable.

\section{Competing interests}

The authors declare that they have no competing interests.

Received: 27 April 2020 Accepted: 19 August 2020

Published online: 14 September 2020

\section{References}

Bae SE, Kim EM, Park JY, Kim JK. Population genetic structure of the grass puffer (Tetraodontiformes: Tetraodontidae) in the northwestern Pacific revealed by mitochondrial DNA sequences and microsatellite loci. Mar Biodivers. 2020a; 50:19 https://doi.org/10.1007/s12526-020-01042-2.

Bae SE, Kim JK, Li C. A new perspective on biogeographic barrier in the flathead grey mullet (Pisces: Mugilidae) from the northwest Pacific. Genes Genom. 2020b;42:791-803 https://doi.org/10.1007/s13258-020-00942-8.

Campana SE. Chemistry and composition of fish otoliths: pathways, mechanisms and applications. Mar Ecol Prog Ser. 1999;188:263-97. https://doi.org/10. 3354/meps188263.

Campana SE. Otolith elemental composition as a natural marker of fish stocks. In: Cadrin SX, Friedland KD, Waldman J, editors. Stock Identification Methods: Applications in Fishery Science. New York: Academic Press; 2005. p. 227-45.

Campana SE, Thorrold SR. Otoliths, increments, and elements: keys to a comprehensive understanding of fish populations? Can J Fish Aquat Sci. 2001;58:30-8 https://doi.org/10.1139/f00-177.

Cardona L. Effects of salinity on the habitat selection and growth performance of Mediterranean flathead grey mullet Mugil cephalus (Osteichthyes, Mugilidae). Estuar Coast Shelf S. 2000;50:727-37 https://doi.org/10.1006/ecss.1999.0594.

Chang CW, lizuka Y. Estuarine use and movement patterns of seven sympatric Mugilidae fishes: the Tatu Creek estuary, central western Taiwan. Estuar Coast Shelf Sci. 2012;106:121-6 https://doi.org/10.1016/j.ecss.2012.04.023.

Chang CW, Tzeng WN, Lee YC. Recruitment and hatching dates of grey mullet (Mugil cephalus L.) juveniles in the Tanshui estuary of northwest Taiwan. Zool Stud. 2000;39:99-106

Chang CW, lizuka Y, Tzeng WN. Migratory environmental history of the grey mullet Mugil cephalus as revealed by otolith Sr:Ca ratios. Mar Ecol Prog Ser. 2004;269:277-88. https://doi.org/10.3354/meps269277.

Chang M, Tzeng W, You C. Using otolith trace elements as biological tracer for tracking larval dispersal of black porgy, Acanthopagrus schlegeli and yellowfin seabream, A. latus among estuaries of western Taiwan. Environ Biol Fish. 2012;95:491-502 https://doi.org/10.1007/s10641-012-0081-7.

Choi YM, Yoo JT, Choi JH, Choi KH, Kim JK, Kim YS, Kim JB. Ecosystem structure and trophic level to the oceanographic conditions around the waters of Jeju Island. J Environ Biol. 2008:29:419-25.

Collins SM, Bickford N, McIntyre PB, Coulon A, Ulseth AJ, Taphorn DC, Flecker AS. Population structure of a neotropical migratory fish: contrasting perspectives from genetics and otolith microchemistry. Trans Am Fish Soc. 2013;142:1192201 https://doi.org/10.1080/00028487.2013.804005.

Daros FA, Spach HL, Sial AN, Correia AT. Otolith fingerprints of the coral reef fish Stegastes fuscus in southeast Brazil: a useful tool for population and connectivity studies. Reg Stud Mar Sci. 2016;3:262-72 https://doi.org/10.1016/j.rsma.2015.11.012. 
DiMaria RA, Miller JA, Hurst TP. Temperature and growth effects on otolith elemental chemistry of larval Pacific cod. Gadus macrocephalus. Environ Biol Fish. 2010;89:453-62 https://doi.org/10.1007/s10641-010-9665-2.

Elsdon TS, Gillanders BM. Alternative life-history patterns of estuarine fish: barium in otoliths elucidates freshwater residency. Can J Fish Aquatic Sci. 2005;62: 1143-52 https://doi.org/10.1139/f05-029.

Elsdon TS, Wells BK, Campana SE, Gillanders BM, Jones CM, Limburg KE, Secor $\mathrm{DH}$, Thorrold SR, Walther BD. Otolith chemistry to describe movements and life-history parameters of fishes: hypotheses, assumptions, limitations and inferences. Oceanogr Mar Biol Annu Rev. 2008;46:297-330.

Fortunato RC, Galán AR, Alonso IG, Volpedo A, Durà VB. Environmental migratory patterns and stock identification of Mugil cephalus in the Spanish Mediterranean Sea, by means of otolith microchemistry. Estuar Coast Shelf. 2017;188:174-80 https://doi.org/10.1016/j.ecss.2017.02.018.

Fazio F, Marafioti S, Arfuso F, Piccione G, Faggio C. Influence of different salinity on haematological and biochemical parameters of the widely cultured mullet, Mugil cephalus. Mar Freshw Behav Phy. 2013;46:211-8. https://doi. org/10.1080/10236244.2013.817728.

Fowler AM, Smith SM, Booth DJ, Stewart J. Partial migration of grey mullet (Mugil cephalus) on Australia's east coast revealed by otolith chemistry. Mar Environ Res. 2016;119:238-44 https://doi.org/10.1016/j.marenvres. 2016.06.010

Gorski K, De Gruijter C, Tana R. Variation in habitat use along the freshwatermarine continuum by grey mullet Mugil cephalus at the southern limits of its distribution. J Fish Biol. 2015;87:1059-71 https://doi.org/10.1111/jfb. 12777.

Hong JM, Yoon JS, Lee TW. Age and growth of flathead grey mullet Mugil cephalus collected by a two-side fyke net in the coastal water off Taean. Korea. Korean J Ichthyol. 2014;26:194-201.

Hsu CC, CW Chang, Y lizuka, WN Tzeng. 2009. A growth check deposited at estuarine arrival in otoliths of juvenile flathead mullet (Mugil cephalus L.). Zool Stud. 2009;48:315-324.

Hwang JH, Van SP, Choi BJ, Chang YS, Kim YH. The physical processes in the Yellow Sea. Ocean Coast Manag. 2014;102:449-57 https://doi.org/10.1016/j. ocecoaman.2014.03.026.

Ibáñez AL, Gutiérrez BO. Climate variables and spawning migrations of the striped mullet and white mullet in the north-western area of the Gulf of Mexico. J Fish Biol. 2004;65:822-31 https://doi.org/10.1111/j.0022-1112.2004.00488.x.

Jones B, Sall J. JMP statistical discovery software. Wiley Interdiscip Rev Comput Stat. 2011;3:188-94.

Ke HM, Lin WW, Kao HW. Genetic diversity and differentiation of gray mullet (Mugil cephalus) in the coastal waters of Taiwan. Zool Sci. 2009;26:421-8 https://doi.org/10.2108/zsj.26.421.

Kim JK, Bae SE, Lee SJ, Yoon MG. New insight into hybridization and unidirectional introgression between Ammodytes japonicus and Ammodytes heian (Trachiniformes, Ammodytidae). PloS One. 2017;12: e0178001. https://doi.org/10.1371/journal.pone.0178001.

Ko JC, Kim JT, Kim SH, Rho HK. Fluctuation characteristic of temperature and salinity in coastal waters around Jeju Island. J Kor Fish Soc. 2007;40:394-410 https://doi.org/10.5657/kfas.2003.36.3.306.

Kwon HK, Seo J, Cho HM, Kim G. Tracing different freshwater sources for nutrients and dissolved organic matter in coastal waters off Jeju Island using radon. Estuari Coast. 2018:1-9 https://doi.org/10.1007/s12237-0180471-y.

Lee JM, Kim G. Estimating submarine discharge of fresh groundwater from a volcanic island using a freshwater budget of the coastal water column. Geophys Res Lett. 2007;34:11 https://doi.org/10.1029/2007GL029818.

Lee YW, Lee JM, Kim G. Identifying sharp hydrographical changes in phytoplankton community structure using HPLC pigment signatures in coastal waters along Jeju Island, Korea. Ocean Sci J. 2009;44:1-10 https://doi. org/10.1007/s12601-009-0001-8.

Lie HJ, Cho CH. Seasonal circulation patterns of the Yellow and East China Seas derived from satellite-tracked drifter trajectories and hydrographic observations. Prog Oceanogr. 2016;146:121-41 https://doi.org/10.1016/j. pocean.2016.06.004

Lie HJ, Cho CH, Lee S. Tongue-shaped frontal structure and warm water intrusion in the southern Yellow Sea in winter. J Geophys Res. 2009;114:C01003 https://doi.org/10.1029/2007JC004683.

Lim C, Park SH, Kim DY, Woo SB, Jeong KY. Influence of steric effect on the rapid sea level rise at Jeju Island, Korea. J Coast Res. 2017;79:189-93 https://doi. org/10.2112/SI79-039.1.
Liu SY, Wang CH, Shiao JC, Dai CF. Population connectivity of neon damsel, Pomacentrus coelestis, inferred from otolith microchemistry and mtDNA. Mar Freshwater Res. 2010;61:1416-24 https://doi.org/10.1071/MF10079.

Miller JA, Banks MA, Gomez-Uchida D, Shanks AL. A comparison of population structure in black rockfish (Sebastes melanops) as determined with otolith microchemistry and microsatellite DNA. Can J Fish Aquat Sci. 2005;62:218998 https://doi.org/10.1139/f05-133.

Moreira C, Froufe E, Sial AN, Caeiro A, Vaz-Pires P, Correia AT. Population structure of the blue jack mackerel (Trachurus picturatus) in the NE Atlantic inferred from otolith microchemistry. Fish Res. 2018;197:113-22 https://doi.org/10. 1016/j.fishres.2017.08.012.

Morrison MA, McKenzie JR, Gillanders BM, Tuck ID. Can otolith chemistry predict the natal origins of grey mullet (Mugil cephalus)? New Zeal Fish Assess Report. 2016;15:68.

Nishimoto MM, Washburn L, Warner RR, Love MS, Paradis GL. Otolith elemental signatures reflect residency in coastal water masses. Environ Biol Fish. 2010; 89:341-56 https://doi.org/10.1007/s10641-010-9698-6.

Park KA, Lee EY, Chang E, Hong S. Spatial and temporal variability of sea surface temperature and warming trends in the Yellow Sea. J Marine Syst. 2015;143: 24-38 https://doi.org/10.1016/j.jmarsys.2014.10.013.

Park MO, Lee YW, Ahn JB, Kim SS, Lee SM. Spatiotemporal distribution characteristics of temperature and salinity in the coastal area of Korea in 2015. J Korean Soc Mar Environ. 2017;20:226-39 https://doi.org/10.7846/ JKOSMEE.2017.20.4.226

Pearce NJ, Perkins WT, Westgate JA, Gorton MP, Jackson SE, Neal CR, Chenery SP. A compilation of new and published major and trace element data for NIST SRM 610 and NIST SRM 612 glass reference materials. Geostandard newslett. 1997;21:115-44.

Proctor $\mathrm{CH}$, Thresher RE. Effects of specimen handling and otolith preparation on concentration of elements in fish otoliths. Mar Biol. 1998;131:681-94 https:// doi.org/10.1007/s002270050360.

Radtke RL, Shafer DJ. Environmental sensitivity of fish otolith microchemistry. Mar Freshwater Res. 1992;43:935-51 https://doi.org/10.1071/MF9920935.

Rooker JR, Secor DH, Zdanowicz VS, Itoh T. Discrimination of northern bluefin tuna from nursery areas in the Pacific Ocean using otolith chemistry. Mar Ecol Prog Ser. 2001;218:275-82. https://doi.org/10.3354/meps218275.

Secor DH, A Henderson-Arzapalo, PM Piccoli. Can otolith microchemistry chart patterns of migration and habitat utilization in anadromous fishes?. J Exp Mar Biol Ecol. 1995;192:15-33. https://doi.org/10.1016/0022-0981(95)00054-U.

Secor DH, Rooker JR. Is otolith strontium a useful scalar of life cycles in estuarine fishes?. Fish Res. 2000;46:359-371. https://doi.org/10.1016/S01657836(00)00159-4.

Shen KN, Jamandre BW, Hsu CC, Tzeng WN, Durand JD. Plio-Pleistocene sea level and temperature fluctuations in the northwestern Pacific promoted speciation in the globally-distributed flathead mullet Mugil cephalus. BMC Evol Biol. 2011;11:83 https://doi.org/10.1186/1471-214811-83.

Shen KN, Chang CW, Durand JD. Spawning segregation and philopatry are major prezygotic barriers in sympatric cryptic Mugil cephalus species. CR Biol. 2015; 338:803-11 https://doi.org/10.1016/j.crvi.2015.07.009.

Sturrock A, Trueman C, Darnaude A, Hunter E. Can otolith elemental chemistry retrospectively track migrations in fully marine fishes? J Fish Biol. 2012;81:766-95.

Traina A, Oliveri E, Manta DS, Barra M, Mazzola S, Cuttitta A. Metals content in otoliths of Dicentrarchus labrax from two fish farms of Sicily. Environ Monit Assess. 2015;187:360 https://doi.org/10.1007/s10661-015-4434-5.

Taillebois L, Barton DP, Crook DA, Saunders T, Taylor J, Hearnden M, Saunders RJ, Newman SJ, Travers MJ, Welch DJ, Greig A, Dudgeon C, Maher S, Ovenden JR. Strong population structure deduced from genetics, otolith chemistry and parasite abundances explains vulnerability to localized fishery collapse in a large Sciaenid fish, Protonibea diacanthus. Evol Appl. 2017;10:978-93. https://doi.org/10.1111/eva.12499.

Wang C, Hsu C, Chang C, You C, Tzeng W. The migratory environmental history of freshwater resident flathead mullet Mugil cephalus L. in the Tanshui River, nothern Taiwan. Zool Stud. 2010;49:504-14.

Wang CH, Hsu CC, Tzeng WN, You CF, Chang CW. Origin of the mass mortality of the flathead grey mullet (Mugil cephalus) in the Tanshui River, northern Taiwan, as indicated by otolith elemental signatures. Mar Pollut Bull. 2011;62: 809-1813 https://doi.org/10.1016/j.marpolbul.2011.05.011.

Wang $\mathrm{CH}$. Otolith elemental ratios of flathead mullet Mugil cephalus in Taiwanese waters reveal variable patterns of habitat use. Estuar Coast Shelf S. 2014;151: 124-30. https://doi.org/10.1016/j.ecss.2014.08.024. 
Yamane K, Shirai K, Nagakura Y, Otake T. Assessing the usefulness of otolith elemental compositions for evaluating the population structure of the Pacific herring Clupea pallasii in northern Japan. Fish Sci. 2012;78:295-307. https:// doi.org/10.1007/s12562-011-0466-0.

Yang S, Youn JS. Geochemical compositions and provenance discrimination of the central south Yellow Sea sediments. Mar Geol. 2007;243:229-41. https:// doi.org/10.1016/j.margeo.2007.05.001

Yoon YH. Marine environments and phytoplankton community around Jeju Island, Korea in the early summer of 2016. Korean J Environ Biol. 2016;34: 292-303 https://doi.org/10.11626/KJEB.2016.34.4.292.

Zhang Cl, Park HW, Kwon HC. Age and growth of the flathead grey mullet (Mugil cephalus) in the coastal water of Yeosu. J Kor Soc Fish Tech. 2011;47:203-13.

Zydlewski J, Wilkie MP. Freshwater to seawater transitions in migratory fishes. In: McCormick SD, Farrell AP, Brauner CJ, editors. Euryhaline fishes, fish physiologyseries. San Diego: Academic Press; 2012. p. 253-326.

\section{Publisher's Note}

Springer Nature remains neutral with regard to jurisdictional claims in published maps and institutional affiliations.

Ready to submit your research? Choose BMC and benefit from:

- fast, convenient online submission

- thorough peer review by experienced researchers in your field

- rapid publication on acceptance

- support for research data, including large and complex data types

- gold Open Access which fosters wider collaboration and increased citations

- maximum visibility for your research: over $100 \mathrm{M}$ website views per year

At BMC, research is always in progress.

Learn more biomedcentral.com/submissions 